\title{
A Engenharia como Base para o Desenvolvimento do País
}

\author{
Ivan Guerra Machado ${ }^{1}$
}

1 Universidade Federal do Rio Grande do Sul - UFRGS, Programa de Pós-graduação em Engenharia de Minas, Metalúrgica e Materiais - PPGE3M, Laboratório de Soldagem \& Técnicas Conexas - LS\&TC, Porto Alegre, RS, Brasil.

Recebido: 25 Nov., 2018

Aceito: 25 Nov., 2018

E-mail: welder@ufrgs.br (IGM)
Este é um artigo publicado em acesso aberto (Open Access) sob a licença Creative Commons Attribution Non-Commercial, que permite uso, distribuição e reprodução em qualquer meio, sem restriçōes desde que sem fins comerciais e que 0 trabalho original seja corretamente citado.
Para que o Brasil alcance níveis relativamente elevados de desenvolvimento econômico e social, é fundamental tornar a Educação uma política de Estado (perene, portanto), sendo de suma importância estabelecer com absoluta clareza que a base sustentável para tanto deve ser o sólido domínio das ciências e das tecnologias, evidentemente sem detrimento das demais atividades ligas às Humanidades.

Porém, deve ser modificado o modelo e a distribuição dos Cursos Superiores que adotamos. Recente pesquisa do INEP [1] mostrou que em 2017, do total de 1.199.769 "concluintes" destes Cursos no nosso país, se formaram aproximadamente na Administração 223.477 (18,6\%); em Direito 113.864 (9,5\%) e em Pedagogia 127.169 (10,6\%), somando nestas três áreas, portanto, mais de 460 mil (38,7\%) pessoas. Porém, todas as Engenharias formaram pífios $113 \mathrm{mil}$ (9,5\%) e, pasme o leitor, 6.335 (0,53\%) para a Física (incluindo Astronomia). Além disto, do total das Engenharias 38\% são da Civil, que somado a Produção situa-se em torno de 55\% de todos os engenheiros diplomados em 2017 no país!

Assim, para aquelas Engenharias que usam e desenvolvem mais intensivamente tecnologias avançadas restaram posições ridículas, tais como (quanto ao total das Engenharias) 11,5\% para Mecânica e, novamente pasme o leitor, 0,3\% para Metalúrgica e $0,7 \%$ para Materiais e Eletrônica, por exemplo.

Em relação à população brasileira formamos $40 \%$ mais no Direito do que a média dos países ditos desenvolvidos que compõem (incluindo os EUA) a Organização para a Cooperação e Desenvolvimento Econômico (OCDE). Porém, também em relação à população, temos cerca de $70 \%$ médicos e a vergonhosa proporção de somente $30 \%$ dos engenheiros que a OCDE possui, sendo isto provavelmente reflexo da

[...] distorção de nosso modelo econômico e de desenvolvimento, que não estimula o empreendedorismo e a inovação, mas a preservação da renda e a opção do empresariado por investir em advogados para proteger sua renda diante de uma burocracia asfixiante, uma legislação desestimulante, entre outros problemas - ao invés de investir em engenheiros (para criar novos produtos) [2].

Então, afinal, qual é o modelo de país que almejamos continuar a viver e legar para as futuras gerações?

Acreditamos que nenhum brasileiro deseja multidões de advogados sem causas, administradores sem empresas e pedagogos sem escolas. Ou a nossa economia deve continuar a se basear essencialmente na agricultura e mineração? Apesar da indiscutível importância de ambas estas atividades, não seria conveniente elas serem as principais, pois o Brasil possui características que demandam elevadas taxas de geração de empregos, condição minimamente atendida pelas produções altamente mecanizadas destas áreas. Além disto, seria uma posição inteligente permanecermos somente como fornecedores de commodities para outras nações, destruindo as montanhas de minérios que possuímos e colhendo da nossa terra os grãos, os quais depois em parte nos serão devolvidos como comidas processadas e quinquilharias inúteis...?

Não seria mais vantajoso para nós e nossos descendentes engajarmo-nos no grande movimento de internacionalização das cadeias produtivas que ocorreu no mundo, com maior desenvolvimento de indústrias e serviços altamente complexos? 
Existem aproximadamente 14 engenheiros por 10 mil habitantes no Brasil e estima-se que para cada 1 milhão de dólares de capital investido é necessário um engenheiro na indústria. Cerca de 300 bilhões de dólares do PIB brasileiro são relativos a investimentos e, corroborando a hipótese mencionada, atualmente o país conta com aproximadamente 300 mil engenheiros [3]. Porém, se a oferta de vagas nas engenharias seguir somente esta métrica, a falta (ou o excesso) de profissionais sempre será dramática, pois sabemos que a formação de um engenheiro não é rápida. Por exemplo, enquanto a participação da indústria de transformação brasileira no PIB entre 2010 e 2017 sofreu queda de aproximadamente 6\%, neste mesmo intervalo (até 2016) o número de cursos de Engenharia aumentou 80\%, (mais do que dobrou no setor privado). Portanto, esta questão deve ser cuidadosamente planejada, pois significativa variação do PIB poderá produzir situação caótica no equilíbrio oferta/demanda de engenheiros formados...

Em recente artigo nesta mesma revista [4], ressaltamos que uma nação somente poderá realmente prosperar se os seguintes fatores estiverem concomitantemente disponíveis: direitos de propriedade; racionalismo científico; mercados de capital (dinheiro disponível para investimento); transporte e comunicações rápidos e eficientes. Apesar de vivermos num país democrático, entendemos existir muito espaço para aperfeiçoarmos estes quatro fatores, ainda que em proporções diferentes, sendo sem dúvida fundamental investirmos maciçamente em ciência e tecnologia.

\section{Referências}

[1] Instituto Nacional de Estudos e Pesquisas Educacionais Anísio Teixeira - INEP. Sinopse estatística da educação superior 2017 - Tabela 1.13. Brasília: INEP; 2018 [Acesso em 19 nov. 2018]. Disponível em: http://portal.inep.gov.br/basica-censo-escolarsinopse-sinopse

[2] Silva Filho RLL. Como fica a Engenharia? O Estado de São Paulo. 13 jul. 2015 [Acesso em 19 nov. 2018]. Edição digital. Disponível em: https://educacao.estadao.com.br/blogs/roberto-lobo/ como-fica-a-engenharia/
[3] Silva Filho RLL. Cursos de Engenharia no brasil: bolha prestes a explodir? O Estado de São Paulo. 29 jul. 2018 [Acesso em 19 nov. 2018]. Edição digital. Disponível em: https://educacao. estadao.com.br/blogs/roberto-lobo/cursos-de-engenhariano-brasil-bolha-prestes-a-explodir/

[4] Machado IG. Introdução às origens da improdutividade no brasil. Soldagem e Inspeção. 2017;22(4):453-465. http://dx.doi. org/10.1590/0104-9224/si2204.05. 